\title{
Practice Model of Read-Examine-Decide-Write Strategy In Strengthening Students' Reading Comprehension
}

\author{
Fitrotul Mufaridah \\ University of Muhammadiyah Jember \\ (mufaridah@unmuhjember.ac.id)
}

\begin{abstract}
Teaching reading in ESP Class is a challenging work not only for the English teacher but also for the students of Islamic Education Program or PAI of University of Muhammadiyah Jember. Teacher should be selective and creative in implementing teaching strategy in order to encourage students to comprehend reading text and communicate their understanding in the target language. The implementation of Read-Examine-Decide-Write (REDW) Strategy was done in ESP class of PAI. Read-Examine-Decide-Write Strategy was found as a good solution to teach them reading comprehension. By grouping the students in pair, they did their learning effectively through the steps of REDW. $75.8 \%$ or 22 of 29 students got score $\geq 75$. They were active in comprehending the text through steps of REDW. The research result showed that Read-Examine-Decide-Write Strategy was able to improve PAI students' reading comprehension in the first semester of 2015-2016 Academic Year.
\end{abstract}

Keywords: reading comprehension, read-examine-decide-write strategy

Reading is an essential skill for all students in all stages. Reading is one of the most important skill of those. It is a process on how readers get information from what they see on text or symbols. Reading comprehension encourages the ability of reader to construct a meaning from the text. The reader should be able to construct the meaning internally from interacting with the material that is read

Reading is very useful for human life because by reading someone would know about the world without having to go around the world. Students can get much information and knowledge by reading activity. In clear explanation, Grabe and Stoller (2002, p. 4) state that reading can be taught as a way to draw information from the text and to form an interpreting information requires the work of brain actively. So, reading activity can encourage students' brain to work much.
In fact, reading is not so easy as what people think because it is not only reading a sentence and saying it out to others, but also how to understand the content of the reading text and its purpose. So it is very crucial for the students to learn English through reading activity.

Reading comprehension is one of the major targets in learning English. Students who learn English should be able to take important information from reading and of course, their teacher is expected to develop reading skill toward educational objectives to support the students' reading activity. Reading comprehension refers to the students' ability to understand the reading text given. However, to comprehend the text, a reader does not only need linguistic knowledge but also they need much background knowledge to support the linguistic one. Having good reading comprehension can support the other 
skills in learning process, but the students often consider that reading is boring. It makes them less motivated and difficult to master English well.

There are some factors that hamper students' English mastery, specifically in reading comprehension. The students may not have much motivation to read because the text is not interesting, and sometimes the text is too long. The students are also unfamiliar with the words used in the text, or they have lack of vocabularies. Moreover, the main factor that causes students to become uninterested in reading is the strategy of teaching reading. Sometimes teachers assume that the students' reading comprehension will be improved naturally without any teaching strategies, In fact, they have significant influences to the students' improvement.

There are many ways to improve reading comprehension. It is improved by strategy, method, approach. But, many teachers still use conventional strategy in teaching reading comprehension. The way of teaching is monotonous and uninteresting. They just ask the students to read the text, identify the difficult words, translate the whole text, and answer the questions based on the text. So, it makes them get bored to study. It makes the students lose their chance to have nice reading class and get what they need in important information or knowledge.

An interview and observation conducted on ESP class of PAI first semester students revealed that they did not find interesting reading class, so they did not have any previous meaningful learning experience in reading English text. PAI Students in the first semester had problems in reading comprehension. Lacking vocabularies posed them in difficult situation to understand reading text comprehensively. It caused them to feel bored and not motivated to practice reading comprehension. Vocabulary problem also makes them difficult to express their understanding and opinion. According to the interview to the students, they did know how to start enjoying reading practice, and understand the text well. They have no good strategy to process learning reading. The experience they got in the previous level could not bring them to find a good progress, both in reading practice and oral expression. They need to have English class which gives them new experiences in doing interactive class of reading. So, they expect their English teacher help them to do the process of learning reading better.

Responding to the students' problem in reading comprehension above, Read-ExamineDecide-Write (REDW) was proposed to be implemented. Gupta (2008, p. 80) stated that REDW is a good strategy to use finding the main ideas in each paragraph of reading assignment. Using this strategy will help the students comprehend the information contained in their assignment. It forces the students to interact with the text. It provides students opportunity to be active in the class, students are motivated to improve their ideas or opinion through asking some questions and answering to find out main ideas that a paragraph points out in a reading task. So Read Examine Decide write (REDW) strategy is a reading strategy that is used specially to find the main idea in the text by following the steps that are provided.

In addition, Gupta (2008, p. 72) states that REDW strategy is both a reading and study skill activity done by making brief notes in the margin of the text. The purpose of this strategy is to provide students' opportunity to be active in class. It is also supported by Liana (2013, p. 6) that the use of REDW strategy could improve student's ability in comprehending descriptive text. This method also helped improve the students' interest and motivation to read.

It was done because the steps of REDW are able to lead the student to do the process of reading comprehension. According to Gupta (2008) that the steps of REDW are as follows: First, the individual should read the paragraph or passage; second, once the individual has identified the main idea of the paragraph, the individual should examine each sentence in the paragraph or passage and write down a 
few words that explain the main idea of each sentence; third, he individual should then decide which words best explain the main idea of the paragraph; finally, the individual should write down the main idea of the paragraph. So, students can start their reading comprehension from the easiest one.

In more detail explanation, Style (2008, p. 1) showed the steps or procedures of Read Examine Decide Write (REDW) strategy. First, reading the paragraph or passage that the individual is having difficulty understanding and attempt to identify the main idea of the paragraph; second, examining each sentence in the paragraph or passage and write down a few words that explain the main idea of each sentence; then, deciding which words best explain the main idea of the paragraph and which words are just describing details that supporting the main idea of the paragraph; and the last, writing down the main idea of the paragraph and any key supporting details that seem important in his or her notes and move into the next paragraph.

\section{Method}

The research design used was Classroom Action Research through spiral of cycles of planning, acting (implementing plans), observing (systematically), reflecting. According to Kemmis and McTaggart (1992, p. $10)$ in Alfian (2013, p. 23) to do action research is to plan,act, observe and reflect more carefully, more systematically, and more rigorously than one usually does in everyday life.

This research began with a preliminary study by interviewing the students to get information about the students' problem in reading comprehension. The planning was constructed to provide students activities by using steps of REDW. In the implementation, the students were guided to do reading activities through steps of REDW strategy. An observation was conducted by the assistant of the class while the implementation done. It was observation about the activities and the applications of steps of REDW. The test of reading comprehension was given to students at the end of the cycle.

The criteria of success used to know whether the implementation of the action achieves the target or not. Based on the preliminary study, 10 of 29 students or $34.4 \%$ had score $\geq 75$. It was then, targeted $75 \%$ of students to have $\geq 75$ score in reading comprehension.

\section{Result and Discussion}

After implementing the steps of REDW, the result of observation showed that 15 of $29(51.7 \%)$ students were active during the teaching learning process of reading comprehension by using Read-ExamineDecide-Write in the first meeting. In the second meeting, there were 19 of 29 (65.5\%) students were active during the teaching learning process of reading comprehension by using Read-Examine-Decide-Write. Meanwhile, the result of the reading comprehension test in cycle 1 showed that the students who could get score $\geq 75$ were only 18 of 29 students or $62 \%$. This result was reflected because of individual work done by students in all steps. The students need to share with their friends in comprehending the reading text. Based on the reflection, it was necessary to conduct the second cycle by grouping the students in pair.

The implementation of REDW in the second cycle could bring the result of observation to be 20 of 29 (68.9\%) students were active during the teaching learning process of reading comprehension in the first meeting, and 25 of 29 (75.8\%) students were active during the teaching learning process of reading comprehension in the second meeting. Meanwhile, the result of the reading comprehension test in cycle 2 showed that the students who could get score $\geq 75$ were 22 of 29 students or $75.8 \%$. Based on the reflection, the action was consequently, stopped because the target score had been achieved.

Reading comprehension test indicated that Read-Examine-Decide-Write (REDW) 
strategy was an effective strategy in teaching and learning English, especially in reading comprehension class of PAI first semester. The present classroom action study was conducted to solve the students' problem in reading comprehension. It was implemented in two cycles to improve students' reading comprehension.

The data collected in the first cycle was from observation checklist and reading comprehension test. The data showed that doing all steps of Read-Examine-DecideWrite (REDW) strategy individually helped the students to improve their reading comprehension. The improvement reached 17 points from $34.4 \%$ to $51.7 \%$. It is in line with Liana (2013, p. 6) explanation that the use of REDW strategy could improve student ability in comprehending text. This strategy also helped the students to improve their interest and motivation to read.

The activities done by the students in the first cycle did not encourage them maximally because they did all the steps of REDW individually. They came into the reading text by their own understanding without any other information or explanation. The reflection then decided that it should be continued to the next cycle because it did not reach the target criteria yet.

Solving the weaknesses of REDW implementation in the first cycle, the way to guide the students in doing the steps of REDW is by grouping them in pair. Doing in pair facilitated the students to share their information and understanding of the reading text. So, they could find the right information and comprehend the writer's meaning better. They could discover the right meaning of the text. It is like what it should be in reading comprehension. Anderson and Pearson in Alexander (1993, p. 160) state successful comprehension involves the reader who can discover the meaning.

Doing in pairs also helped the students to find a particular piece of information, solve a problem through reading, work to understand an idea or follow a set of directions. REDW strategy facilitated them to formulate their reading comprehension processes maximally. It proved Strichart $(2009$, p. 80$)$ statement that this strategy could be used to assess deep understanding of students through questioning and also analyze the problem to get the main idea about the problem. From the point of view, it can be understood that reading is an active thinking process where the reader tries to gain information given by the author and understands what actually the purpose of the author.

Moreover, Gupta (2008, p. 72) stated that Read-Examine-Decide-Write (REDW) strategy is both a reading and study skill activity done by making brief notes in the margin of the text. Practicing the steps of REDW strategy in pairs really helped the students to comprehend the information contained in their assignment. It forced the students to interact with the text. It provided students' opportunity to be more active in the reading class. It also motivated the students to improve their ideas or opinion through asking some questions and answering to find out main ideas that paragraph points out in a reading task.

The condition of the students also became much better than before. The students felt more enjoyable and interested in learning reading comprehension by using ReadExamine-Decide-Write (REDW) strategy. It was showed by their enthusiasm and attention when they followed the lesson actively and listened carefully to the teacher's explanation.

Reflecting the result of observing, it was found that the students' reading comprehension score improved from 51.7\% in cycle 1 to $75.8 \%$ in cycle 2 . It reached 24.1 points of improvement in cycle 2 . So, it already found the target score criteria. The result of the research, showed that the implementation of Read-Examine-Decide-Write (REDW) strategy by grouping the students in pair could improve reading comprehension of PAI first semester students. 


\section{Conclusion}

The reflection of cycle 2 showed that there was reading comprehension improvement performed by the students. The students who got score $\geq 75$ were already $75.8 \%$ or 22 of 29 students of PAI first semester. So, it can be concluded that applying Read-ExamineDecide-Write strategy improve the students reading comprehension of PAI first semester by grouping them in pair for sharing the information and discussing the main idea of the text. This strategy also helped the students to strengthen their interest and motivation to read. The condition of the students in class activities also became much better than before. The students felt more enjoyable and interested in learning reading comprehension.

\section{References}

Anderson, Mark and Kathy Anderson. (1998). Text Types In English. Malaysia : National of library of Australia.

Arikunto, Suharsimi. (2010). Prosedur Penelitian Suatu Pendekatan Praktik. Jakarta: Rineka cipta.

Brunner, Jurdy Tilton. (2012). Now I get it !: Helping Students Understand What They Read. Kingdom: Rowman \& littlefield publisher, Inc.

Cameron, Lynne. (2001). Teaching languages to young learners. United kingdom: Cambridge university pers.

Carter, Carol. (2008). Keys to be effective learning. Singapore: Pearson Prentice Hall.

Gupta, Sadhana. (2008). Communication Skills and Functional Grammar. New Delhi : University Science Press.

Harmer, Jeremy. (1998). How to teach English. Malaysia: Longman.

Linse and Nunan. (2005). Practical English language teaching young learners.
Newyork: McGraw-Hill.

Macceca, Stephanie. (2007). Reading Strategies for Science. New York: Shell Education.

Nunan, David. (2003). Pratical English Language Teaching. Singapore: McGrawHill education. 
